\title{
Critical ELT in Action: Foundations, Promises, Praxis by Graham V. Crookes
}

\author{
George M. Jacobs \\ James Cook University, Singapore \\ Harumi Kimura \\ Miyagi Gakuin Women's University, Japan
}

Crookes, G. V. (2013). Critical ELT in action: Foundations, promises, praxis. New York, NY: Routledge.

The word "critical" has been around in linguistics and education since at least the 1970s, with terms such as "critical linguistics" and "critical pedagogy" being used. Critical ELT in Action offers an example-rich explanation of how "critical" might be applied to English Language Teaching. The author, Graham Crookes, wastes no time, as the first paragraph of the introduction offers a definition of "critical" as applied to education as:

[A] perspective on teaching, learning, and curriculum that doesn't take for granted the status quo, but subjects it to critique, creates alternative forms of practice, and does so on the basis of radical theories of language, the individual, and society that take seriously our hopes for improvement in the direction of goals such as liberty, equality, and justice for all. (p. 1)

The three goals that Crookes highlights—liberty, equality, and justice-are appropriate in any context at any time. However, the book is particularly timely, as these goals are receiving increased attention, especially in the developing world, including Asia. For instance, social justice is now highlighted in UNESCO campaigns for education for sustainable development (UNESCO, 2012). Similarly, campaigns for environmental protection now speak of "green justice" (Asian Development Bank, 2012).

Even with this international momentum for social change, Crookes appreciates that many of his readers may be reluctant to embrace a critical perspective in their work in ELT. Thus, he recommends small steps, even very small steps. To guide readers in taking these steps, the book raises many important points to consider when attempting critical ELT. This review is organized around a presentation of some of those points in the order in which they appear in the book. 


\section{Points To Consider in Implementing Critical ELT}

The main section of this review addresses points that ELT practitioners may wish to consider when attempting to utilize a critical perspective on their teaching. A first point involves whether and to what extent to use prepared materials or instead to use materials created ad hoc by students and teachers as issues emerge from the lives of those in the classroom (Chapter 1). The impetus for ad hoc materials follows in the footsteps of Freire's (1973) groundbreaking literacy work with poor adults in Brazil. Freire did not use previously prepared teaching materials; instead, he used drawings based on students' lives as a means of working with students to generate language learning materials.

A second point raised by Crookes asks to what extent should language-focused topics, such as grammar, text types, and reading strategies, be used, rather than confining the class to social issues topics, such as work, health, education, family, culture, anti-racism, gender equality, and utopia and how to move toward it (Chapter 1). The hope is that language learning goals can be achieved while discussing social issues topics. In fact, student motivation to learn language may increase via the use of such topics.

When exploring critical ELT, practitioners might also want to consider if the internet, including social media, can be a tool for comprehensible student-generated materials and for students to share and develop their knowledge and views. One example might be petition sites (e.g., The Petition Site, n.d.) that allow anyone to create and promote a petition on issues of his or her choice As access to technology expands, Web 2.0 tools are coming within the reach of even students from average income families in poor countries (Chapters 1 and 7).

Crookes explains that critical ELT is not just about content; how to teach is also important. For instance, students may be uncomfortable with more participatory classroom structures and activities (Chapter 2). Should teachers start slowly with one small pedagogic change at a time? That seems to be the approach advocated by Auerbach and Wallerstein (1987, p. 46):

"[S]tudents naturally expect a hierarchical style of education, similar to their previous learning experiences. It is important, therefore, to start with structured activities at the same time that you are creating an environment for student-directed learning."

An oft-raised issue in ELT, an issue which links to critical pedagogy, is the extent to which students' first languages be used, especially in EFL contexts, with students currently at low proficiency levels, and with students whose first language may be endangered (Endangered Languages, n.d.) (Chapter 2). From both a justice perspective and from a general pedagogic perspective, some first language use may make sense (Jacobs \& Kimura, 2013; Norton, 2000).

Regardless of the language students use, spoken and written dialogue is highly valued in critical pedagogy (Chapter 2). Crookes (p. 64) highlights the importance of critical dialogue and defines it as taking place when "one person's language, whether statement or question, encourages or presses another to consider the basis for their thinking." This definition brings to mind a different but related meaning of "critical," the meaning from the literature on critical and creative thinking (Kuhn \& Crowell, 2011). For instance, here is one rather long definition from two well known names in critical and creative thinking (Scriven \& Paul, 1987, cited in The Critical Thinking Community, 2013, para. 3): 
... the intellectually disciplined process of actively and skillfully conceptualizing, applying, analyzing, synthesizing, and / or evaluating information gathered from, or generated by, observation, experience, reflection, reasoning, or communication, as a guide to belief and action. In its exemplary form, it is based on universal intellectual values that transcend subject matter divisions: clarity, accuracy, precision, consistency, relevance, sound evidence, good reasons, depth, breadth, and fairness.

In the reviewers' experience, too often dialogue between teachers and students and among students remains at a rather superficial level, challenging neither the intellect nor the emotions, and failing to connect with the interlocutors' lives on a deep level.

Dialogue provides an important element in democracy, and critical pedagogy advocates forms of democratic practices in and out of the class. This advocacy raises the issue of the extent to which classrooms can be democratic (Chapter 3). For instance, what happens if students can vote, and their decisions go against their teacher's view and school policy? What happens if students vote to have no exams or grades or if students vote in favor of unjust policies?

Critical pedagogy draws ideas from many sources, including critical linguistics. Critical linguists believe that language is not neutral and, in some cases, may support the status quo (Chapter 3 and 5). For example, in English, use of "generic he," i.e., using the masculine pronoun or masculine nouns to represent all people, e.g., "Man should live in harmony with nature," is said to reinforce the inferior position of females in society (Rubin, Greene, \& Schneider, 1994). Crookes (pp. 88-89) quotes Fowler (1991), "The prevailing orthodoxy of linguistics is that it is a descriptive discipline which has no business passing comments on materials which it analyses; neither prescribing usage nor negatively evaluating the substance of its enquiries" [italics in original]. Critical linguistics finds inspiration in various theories of language (Chapter 5). In particular, Crookes reports work in critical teaching that utilized Systemic Functional Linguistics (Halliday, 1973). Indeed, linguists inspired by that theory have done a great deal of work with disadvantaged populations in Australia and elsewhere (e.g., Christie, et al., 1991).

When attempting something different, such as critical ELT, past examples can serve as models and provide inspiration. Fortunately, Crookes (Chapter 4) offers examples of, as the book's title promises, "critical ELT in action." Furthermore, interested readers can find other sources, such as the Peace as a Global Language Conference (Peace as a Global Language, n.d.).

Additionally, topics such as justice and equity seem to be increasingly common in discourse on education.

Critical pedagogy encourages education stakeholders to cooperate to increase their skills and power (Chapter 5). Duncan-Andrade and Morrell (2008) describe such collaborations of teachers as groupings in which members share goals, interact to further those goals, negotiate how and on what they will cooperate, learn together, and develop a shared culture, including the terms they use and the ways that they go about achieving their goals.

Conscientization, which is a kind of ongoing reflection on their actions for social improvement, constitutes a key goal and teaching tool in critical pedagogy (Chapter 5). This conscientization involves thoughtful study of the world and students' roles in it, rather than students being confined to emotional responses and impulsive actions. While Crookes highlights the need for action, it must be thoughtful action in order to succeed on social and educational fronts. 
One way of taking action to improve society can be to link with ongoing social movements (Chapter 6). Some of those social movements suggested by Crookes are feminism, workers' rights, anti-racism, equal rights regardless of sexual identity, environmental protection, peace, and multiculturalism. Such movements often have specially designed programs for use with students. Also, they may welcome visits by students and offer opportunities for internships. Depending on the teachers' backgrounds, teachers differ in how they raise the issues championed by various social movements? For instance, how might homosexual and heterosexual teachers differently raise issues related to sexual identity?

Crookes includes many tasks to encourage readers to reflect, explore, share experiences and opinions, exemplify, share materials, search, correspond, explore resources, compare, plan, and inquire. For instance, one task (Chapter 6) asks readers to reflect on whether inclusion in course materials on environmental destruction necessarily constitutes promotion of critical perspectives. Readers are then asked to find such environmental content in teaching materials and to consider how this content provides opportunities for encouraging critical perspectives.

Teachers work in many different educational contexts; for instance, while most teachers work in mainstream schools, others teach in alternative education settings (Chapter 7). Examples of alternative education settings include online education systems, community schools, private language schools, and charter schools. Readers who teach in such alternative contexts or who are considering shifting to them will welcome that Crookes cites examples of some critical ELT in those settings.

Teachers who seek to implement critical perspectives on education are not confined to their classrooms or even their school. Critical ELT teachers can step outside their classrooms and advocate to the public and policy makers for programs and on policy issues (Chapter 7). Here, Crookes explores areas such as fund raising, developing networks of organizations, and promoting effective forms of leadership. Similarly, students can move from classroom learning on social justice issues to out-of-class activism on those issues (Chapter 8). Crookes (p. 188) highlights the need to take that step:

[M] erely being informed about injustice or inequity, even affecting oneself, does not necessarily lead to any form of action even when conditions are relatively favorable. Rather, it is through being socialized into forms of active citizenship that a disposition and an understanding of what is involved comes into being; there is a change in identity, one might say.

Of course, teachers are not the only educators who can try out critical pedagogy.

Administrators, too, can promote critical pedagogy (Chapter 7), and, thus, provide a new vision of educational leadership. In this regard, Crookes offers ideas, such as replacing top-down leadership, encouraging all stakeholders to make their voices heard, and developing democratic practices throughout the school.

One of the most frequently heard criticisms of critical pedagogy is that critical teachers are attempting to impose their views on students and others (Chapter 8). "Indoctrination" is an even stronger word than "imposition," and both are used to condemn critical pedagogy. In response, Crookes (p. 179) favorably quotes Nagai (1976) as stating, "What determines whether teaching becomes indoctrination is not so much the points of view a teacher wants to stress as the ways in which he expresses his views." 
A related concern involves what teachers should do if students do not seem interested in topics that the teachers might feel are life and death matters of social justice, such as preventing the use of children as soldiers (Chapter 8). Indeed, the authors of this review have heard many colleagues state that students' main interests involve personal interests, such as travel, food, personal relationships, and other matters relating to how to individualistically enjoy life. Students may well not want to spend time on such "depressing" topics as the doom that humans, especially those in the middle and upper classes, are bringing down upon the world via human-induced climate change (Steffen et al., 2011). For instance, Crookes cites Shor (1992), a leading figure in critical pedagogy, who recounted raising an anti-individualist topic in his class. Upon finding students unwilling to discuss the topic, Shor dropped it, as for him as teacher to insist on the topic would have contradicted critical pedagogy's emphasis on democracy.

Finally, understanding and action require imagination (Chapter 9). Crookes argues that imagination can play a powerful role in inspiring students to work toward bringing into being their imagined, more just, world. For instance, to appreciate the thoughts and feelings of the more than 40 billion chickens trapped in the hell that is life on factory farms, students need to deploy their imaginations. Similarly, imagination plays a role in visualizing how to alleviate the chickens' plight and what our world might be like when humans no longer view chickens as sources of food.

\section{Conclusion}

In ELT, international organizations such as IATEFL (International Association of Teachers of English as a Foreign Language) and TESOL (Teachers of English to Speakers of Other Languages) have for many years had special interest groups that deal with social justice issues (IATEFL Global Issues SIG, 2013; TESOL International Association, 2014). Similar subgroups can be found in other ELT organizations, e.g., the Japan Association for Language Teaching's Global Issues in Language Education group (Japan Association for Language Teaching, 2008). For ELT practitioners keen to pursue similar efforts, Critical ELT in Action is a valuable book, as it builds on a wide range of past experience and offers guidance for the future.

Books are of a finite length and need to address multiple audiences. Thus, no one book is likely to completely please every reader. With that in mind, two areas that would have made the reviewers even more pleased with the book are greater comprehensibility for novice readers and inclusion of an additional social justice domain. As to comprehensibility, in general, Crookes does a good job of scaffolding important terms and concepts. However, at times, especially when quoting others, Crookes might have either summarized rather than quoted or provided additional glossing. For instance, many readers may feel lost several times in the quote from Peters (1995) on page 115, including when encountering "non-reductive way" and "essentialist readings."

As to adding a social justice concern, one issue that is receiving increased attention, especially in the developed world, is the plight of non-human animals, in particular, the animals whom humans eat. The United Nation's Food and Agricultural Organization estimates put at over 60 billion the number of land animals killed annually to be eaten by humans, and this does not include similarly huge numbers of marine animals (Worldwatch Institute, 2013). Many of these sentient beings, even the marine animals, suffer short, horrid, unnatural lives on what have come to be called factory farms, due to the fact that on what the meat industry calls Concentrated Animal Feeding Operations, these thinking, feeling beings are treated as though they were so many objects on a factory's assembly line. 
To conclude, the status quo does not work for many humans and other sentient beings. Two cold numbers drive this home: (1) someone, often a child less than five years old, dies of malnutrition every 3.6 seconds (UNESCO, n.d.); (2) the statistic from the previous paragraph about 60 billion land animals (not to mention marine animals) being killed each year for food for humans. Should these and other social justice issues be some part, however small, of English teaching? Readers who believe they should may well want to put into practice some of the many ideas shared in Critical ELT in Action.

\section{Author Note}

George M. Jacobs, James Cook University, Singapore; Harumi Kimura, Miyagi Gakuin Women's University, Miyagi, Japan.

Correspondence concerning this article should be addressed to George M. Jacobs, James Cook University, 600 Upper Thomson Road, Singapore 574421; Harumi Kimura, Miyagi Gakuin Women's University, 9-1-1 Sakuragaoka, Aoba Ward, Sendai, Miyagi Prefecture 981-0961, Japan. E-mail: george.jacobs@gmail.com; kharumi@mgu.ac.jp 


\section{References}

Asian Development Bank. (2012). 12 things to know: Upholding environmental laws in Asia and the Pacific. Retrieved from http://www.adb.org/features/12-things-know-2012green-justice-asia-and-pacific

Auerbach, E. R., \& Wallerstein, N. (1987). ESL for action: Teacher's guide. New York, NY: Prentice-Hall.

Christie, F., Devlin, B., Freebody, P. Luke, A. Martin, J. R., Threadgold, T., \& Walton, C. (1991). Teaching critical social literacy: A project of national significance on the preservice preparation of teachers for teaching English literacy. Canberra, Australia: DEET.

Duncan-Andrade, J. M., \& Morrell, E. (2008). The art of critical pedagogy: Possibilities for moving from theory to practice in urban schools. New York, NY: Peter Lang.

Endangered Languages. (n.d.). The world through 3230 lenses. Retrieved from http://www.endangeredlanguages.com

Fowler, R. (1991). Language in the news: Discourse and ideology in the press. London, England: Routledge.

Freire, P. (1973). Education for critical consciousness. New York, NY: Seabury Press.

Halliday, M. A. K. (1973). Explorations in the functions of language. London, England: Edward Arnold.

IATEFL Global Issues SIG. (2013). Welcome to GIS/G. Retrieved from http://gisig.iatefl.org

Jacobs, G. M., \& Kimura, H. (2013). Encouraging second language use in cooperative learning groups. Beyond Words, 1(1), 24-37. Retrieved from

http://journal.wima.ac.id/index.php/BW

Japan Association for Language Teaching. (2008). Global Issues in Language Education SIG. Retrieved from http://jalt.org/groups/599

Kuhn, D., \& Crowell, A. (2011). Dialogic argumentation as a vehicle for developing young adolescents' thinking. Psychological Science, 22(4), 545-552. http://dx.doi.org/10.1177/0956797611402512

Nagai, M. (1976). Education and indoctrination: The sociological and philosophical bases. Tokyo, Japan: University of Tokyo Press.

Norton, B. (2000). Identity and language learning: Gender, ethnicity and educational change. Essex, United Kingdom: Pearson Education.

Peace as a Global Language. (n.d.). About peace as a global language. Retrieved from http://pgljapan.org/about-2

Peters, M. (1995). Radical democracy, the politics of difference, and education. In B. Kampol \& P. McLaren (Eds.), Critical multiculturalism (pp. 39-57). Westport, CT: Bergin \& Garvey.

Rubin, D. L., Greene, K., \& Schneider, D. (1994). Adopting gender-inclusive language reforms: Diachronic and synchronic variation. Journal of Language and Social Psychology, 13, 91-114. http://dx.doi.org/10.1177/0261927X94132001

Shor, I. (1992). Empowering education: Critical teaching for social change. Chicago, IL: University of Chicago Press.

Steffen, W., Persson, Å., Deutsch, L., Zalasiewicz, J., Williams, M., Richardson, K., ... \& Svedin, U. (2011). The Anthropocene: From global change to planetary stewardship. Ambio, 4O(7), 739-761. http://dx.doi.org/10.1007/s13280-011-0185-x

TESOL International Association. (2014). Social responsibility. Retrieved from http://www.tesol.org/connect/interest-sections/social-responsibility

The Critical Thinking Community. (2013). Defining critical thinking. Retrieved from https://www.criticalthinking.org/pages/defining-critical-thinking/766

The Petition Site. (n.d.). Care2 petition site. Retrieved from http://www.thepetitionsite.com

UNESCO (2012). World Day of Social Justice. Retrieved from http://www.unesco.org/new/en/media-services/singleview/news/world_day_of_social_justice/\#.U1xwTvmSySo 
UNICEF. (n.d.). Millennium development goals. Retrieved from http://www.unicef.org/mdg/poverty.html

Worldwatch Institute. (2013). Meat production continues to rise. Retrieved from http://www.worldwatch.org/node/5443 